\title{
Characteristics of Polish Isolates of Fusarium sambucinum: Molecular Identification, Pathogenicity, Diversity and Reaction to Control Agents
}

\author{
Anna Baturo-Ciesniewska • Leszek Lenc • \\ Andrzej Grabowski • Aleksander Lukanowski
}

Published online: 25 July 2014

(C) The Author(s) 2014. This article is published with open access at Springerlink.com

\begin{abstract}
Pathogenicity of 28 Polish isolates of F. sambucinum to potato tubers, their sensitivity to control agents, diversity among isolates and molecular methods of species identification were examined. All isolates were pathogenic to potato tubers and differences in pathogenicity were found. Isolates on the PDA were classified into three different color groups of mycelium (B - bright-beige, $\mathrm{P}$ - salmon pink, $\mathrm{R}$ - rose) that varied in pathogenicity and mycelium growth rate on PDA. P colonies showed the greatest tuber damage, but they grew the slowest on the PDA. Isolates showed varied reaction to different concentrations of 4 control agents (M mancozeb, C- captan, CO - copper oxychloride and GE grapefruit extract). The highest mycelium growth inhibition (MGI) was caused by M and the lowest by CO. Strong MGI by GE was observed especially for $\mathrm{P}$ isolates. Individual isolates showed different susceptibility to the control agents. Identification of isolates was determined in PCR assay with species specific FSF1/FSR1 primers, by sequencing of DNA fragments derived from ITS regions and the translation elongation factor-1 alpha gene (TEF). Sequence of the ITS regions were identical for all isolates. Analysis of the TEF DNA fragments showed one SNP (transition $\mathrm{C} \leftrightarrow \mathrm{T}$ ) in the sequences of isolates from the three different color groups.
\end{abstract}

Resumen Se examinaron la patogenicidad de 28 aislamientos polacos de $F$. sambucinum de tubérculos de papa, su sensibilidad a agentes de control, su diversidad entre

\footnotetext{
A. Baturo-Ciesniewska $(\bowtie) \cdot$ L. Lenc $\cdot$ A. Lukanowski Department of Entomology and Molecular Phytopathology Faculty of Agriculture and Biotechnology, University of Technology and Life Sciences, Kordeckiego St. 20, Bydgoszcz 85-225, Poland e-mail: baturo-a@utp.edu.pl

A. Grabowski

Institute of Mathematics and Physics, University of Technology and Life Sciences, Kaliskiego St. 7, Bydgoszcz 85-796, Poland
}

aislamientos y métodos moleculares de identificación de especies. Todos los aislamientos fueron patogénicos a los tubérculos de papa y se encontraron diferencias en patogenicidad. Se clasificaron aislamientos en PDA en tres diferentes grupos de color del micelio (B - crema brillante, $\mathrm{P}$ rosa salmón, $\mathrm{R}$ - rosa) que variaron en patogenicidad y en nivel de crecimiento del micelio en PDA. Las colonias P mostraron el mayor daño de tubérculo, pero fueron las de crecimiento más lento en PDA. Los aislamientos mostraron varias reacciones a diferentes concentraciones de cuatro agentes de control ( $\mathrm{M}$ - mancozeb, $\mathrm{C}$ - captan, $\mathrm{CO}-$ oxicloruro de cobre, y GE - extracto de toronja). La mayor inhibición de crecimiento de micelio (MGI) fue causada por M y la más baja por CO. Se observó fuerte MGI por GE, especialmente para los aislamientos P. Aislamientos individuales mostraron diferente susceptibilidad a los agentes de control. Se determinó la identificación de los aislamientos en ensayos de PCR con iniciadores específicos por especie FSF1/FSR1 mediante la secuenciación de fragmentos de ADN derivados de regiones ITS y la traducción del factor-1 de elongación del gen alpha (TEF). La secuencia de las regiones ITS fueron idénticas para todos los aislamientos. El análisis de los fragmentos del ADN TEF mostraron una SNP (transición $\mathrm{C} \leftrightarrow \mathrm{T}$ ) en las secuencias de los aislamientos de los tres diferentes grupos de colores.

Keywords Fusarium sambucinum · Potato · Pathogenicity · Control · ITS · TEF

\section{Introduction}

Poland is one of the largest potato producers in the world after China, India, Russian Federation, Ukraine, United States and Germany. Although its growing area has decreased in recent years, the potato is still one of the most common crops grown 
in Poland (http 1- Faostat 2012; http 2- Polish Central Statistical Office 2012).

Fusarium sambucinum Fückel, teleomorph Gibberella pulicaris (Fries) Sacc. (Leslie and Summerell 2006) along with a few other species from the Fusarium genus causes dry rot, which is one of the major diseases of potato tubers that can occur both in the field and in storage, especially in North America and many parts of Europe (Boyd 1972; Desjardins 1995; Hanson et al. 1996; Hooker 1981; Peters et al. 2008; Secor and Salas 2001). Yield losses due to dry rot can be up to $25 \%$ (Chelkowski 1989), but losses greater than $60 \%$ of potato tubers in storage have also been reported (Stevenson et al. 2001; Theron 1991). Fusarium sambucinum is considered to be a toxigenic species, known to produce e.g. trichothecenes (15-monoacetoxyscirpenol and 4,15diacetoxyscirpenol mainly), sambutoxin and enniatins (Altomare et al. 1995; Desjardins and Plattner 1989; Kim et al. 1995).

Because of the importance of potato and the extent of losses caused by Fusarium spp., effective protection by seed treatment and postharvest application of control substances in storage is very important (Hanson et al. 1996; Nolte et al. 2003). To develop appropriate plant breeding programs, knowledge of intraspecific diversity in the population of the fungus is also relevant (McDonald and Linde 2002).

The purpose of this study was to investigate the pathogenicity of 28 isolates of $F$. sambucinum to potato tubers, sensitivity of the fungus to control agents and diversity among the isolates including genetic features.

\section{Materials and Methods}

\section{Collection and Isolation of $F$. sambucinum}

Twenty-eight isolates of $F$. sambucinum were collected from potato tubers of different cultivars of potato (Solanum tuberosum L.) with dry rot disease symptoms in different Polish provinces (Table 1).

The tubers were washed in tap water, disinfected in $94 \%$ ethyl alcohol for $1 \mathrm{~min}$, washed in sterile water and shaken in $7 \% \mathrm{H}_{2} \mathrm{O}_{2}$ for $15 \mathrm{~min}$ and then washed three times in sterile water. To isolate the fungus $2 \times 2 \mathrm{~mm}$ fragments of the tuber, from the border between healthy and diseased tissue, were cut using a sterile scalpel. After drying on sterile blotting paper, the fragments were placed on PDA, pH 5.5 (Potato Dextrose Agar, Difco, USA). After 7 days of incubation in the dark at $23{ }^{\circ} \mathrm{C}$, pure cultures were placed first into slants with a PDA medium, next onto Petri dishes with a PDA medium and then were preliminary identified based on conidial morphology (Leslie and Summerell 2006). Single spore cultures were prepared in sterile conditions by transferring, with the use of a sterile needle, single germinated conidia obtained on $2 \%$ water agar according to Baturo-Ciesniewska and Suchorzynska (2011). Final identification was carried out in PCR assays.

Reaction to control agents, growth and color of mycelium on PDA

Reaction of $F$. sambucinum isolates to fungicides mancozeb (M) (Dithane NeoTec 75 WG, Dow AgroSciences, Poland), captan (C) (Kaptan Zawiesinowy 50 WP, Organika-Azot, Poland), copper oxychloride (CO) (Miedzian $50 \mathrm{WP}$, Organika-Azot, Poland) and also to grapefruit extract (GE) (Biosept 33 SL, Cintamani, Poland), used to control seed piece decay or potato diseases, was tested in a radial growth assay on Petri dishes. Mycelial plugs $(0.5 \mathrm{~cm}$-diameter) from 10-day-old cultures were placed at the center of PDA plates amended with concentrations of 10,50 and $100 \mathrm{ppm}$ of the mentioned substances. Additionally, $330 \mathrm{ppm}$ and $500 \mathrm{ppm}$ of GE were tested due to the potential practical use of these higher concentrations. Growth on PDA was evaluated as a control. The experiment was carried out in three replications. Plates were incubated in the dark at $23^{\circ} \mathrm{C}$. Colony diameters were measured after 3 and 6 days post inoculation. The average daily growth of mycelium [mm] was determined and the degree of mycelium growth inhibition (MGI) was calculated in comparison to the control plates.

Also growth rate of mycelium per day measured on 3rd and 6th day after the inoculation on control dishes was used to compare isolates. On the 14th day isolates were divided into 3 main color groups: $\mathrm{B}$ - isolates with bright, beige mycelium, $\mathrm{P}$ - bright salmon pink mycelium and $\mathrm{R}$ - rose, carmine mycelium. It was verified if isolates classified into the three different color groups differed in growth rate, pathogenicity to potato tubers, and reaction to control agents. Also, the probability of the occurrence of each of the three colors was determined.

\section{Pathogenicity Test}

Colonies of $F$. sambucinum for infection of potato tubers were grown on Petri dishes with SNA medium for 14 days. Tubers were inoculated with a $0.5 \mathrm{~cm}$ disc cut from the medium with mycelium that had a high concentration of conidia. Healthy, medium-sized tubers of moderately susceptible cv. Bard were washed carefully in tap water, disinfected by immersion in $1 \% \mathrm{NaOCl}$ for $3 \mathrm{~min}$. and washed in sterile water. After drying, a piece of tissue was cut out with a sterile cork drill (5 $\mathrm{mm}$ diameter and $10 \mathrm{~mm}$ depth), the discs with fungus were put in the hole and the removed fragment was replaced as a stopper. The pathogenicity test was carried out with three replications for each isolate. One replication was five tubers inoculated with one $0.5 \mathrm{~cm}$ disc of mycelium. Control samples 
Table 1 Characteristics of the 28 isolates of F. sambucinum

\begin{tabular}{|c|c|c|c|c|c|c|c|}
\hline \multirow[t]{2}{*}{ Code of isolate } & \multicolumn{2}{|l|}{ Origin } & \multirow[t]{2}{*}{ Colour of mycelium on PDA } & \multicolumn{2}{|c|}{ Pathogenicity for potato tubers } & \multicolumn{2}{|c|}{$\begin{array}{l}\text { Mean growth of mycelium on } \\
\text { PDA }\end{array}$} \\
\hline & Potato cultivar & Location & & {$[\mathrm{mm}]$} & homoge-neous groups & {$[\mathrm{mm}]$} & homoge-neous groups \\
\hline $\mathrm{Fsa} 0525^{\mathrm{a}}$ & Vineta & Słabomierz, N-W ${ }^{b}$ & $\mathrm{~B}^{\mathrm{c}}$ & $20.51^{\mathrm{d}}$ & $\mathrm{bcd}^{\mathrm{e}}$ & $13.39^{\mathrm{f}}$ & $\mathrm{jkl}$ \\
\hline Fsa0526 & Kuklik & Słabomierz, N-W & $\mathrm{B}$ & 21.78 & de & 13.58 & $\mathrm{jkl}$ \\
\hline Fsa0528 & Ibis & Słabomierz, N-W & $\mathrm{P}$ & 15.45 & $a b c$ & 12.25 & defghijk \\
\hline Fsa0530 & Albina & Bonin, N-W & $\mathrm{B}$ & 20.22 & bcd & 8.60 & a \\
\hline Fsa0539 & Victoria & Mielno, N-E & $\mathrm{B}$ & 23.33 & defgh & 12.67 & ghijkl \\
\hline Fsa0540 & Bila & Niewieścin, N-W & $\mathrm{P}$ & 20.22 & bcd & 10.75 & bcd \\
\hline Fsa0542 & Dorota & Zamarte, N-W & $\mathrm{P}$ & 29.44 & $\mathrm{ij}$ & 12.63 & fghijkl \\
\hline Fsa0543 & Asterix & Gościnno, N-W & $\mathrm{P}$ & 78.89 & $\mathrm{k}$ & 12.03 & defghij \\
\hline Fsa0551 & Neptun & Jadwisin, C & $\mathrm{P}$ & 22.33 & de & 10.94 & bcde \\
\hline Fsa0552 & Irga & Jadwisin, C & $\mathrm{P}$ & 21.00 & $\mathrm{~cd}$ & 11.54 & cdefgh \\
\hline Fsa0553 & Kuklik & Mrocza, N-W & $\mathrm{P}$ & 22.45 & de & 12.88 & hijkl \\
\hline Fsa0555 & Ibis & Jankowo, N-W & $\mathrm{B}$ & 28.33 & fghi & 12.54 & efghijkl \\
\hline Fsa0557 & Bila & Zamarte, N-W & $\mathrm{B}$ & 28.78 & hij & 12.50 & efghijkl \\
\hline Fsa0637 & Gracja & Kruszyn Kraj., N-W & $\mathrm{P}$ & 34.00 & $\mathrm{j}$ & 9.39 & $a b$ \\
\hline Fsa0709 & Orlik & Osiny, S-E & $\mathrm{B}$ & 32.00 & $\mathrm{ij}$ & 13.42 & $\mathrm{jkl}$ \\
\hline Fsa0718 & Drop & Osiny, S-E & $\mathrm{B}$ & 22.11 & de & 13.92 & 1 \\
\hline Fsa0719 & Gracja & Osiny, S-E & $\mathrm{P}$ & 28.22 & fghi & 9.38 & $\mathrm{ab}$ \\
\hline Fsa0720 & Korona & Osiny, S-E & $\mathrm{R}$ & 20.67 & bcd & 13.22 & ijkl \\
\hline Fsa0726 & Vineta & Włościbórz, N-W & $\mathrm{B}$ & 10.56 & $\mathrm{a}$ & 11.00 & bcdef \\
\hline Fsa0727 & Denar & Wiśniewka, N-W & $\mathrm{R}$ & 23.00 & defg & 12.15 & defghijk \\
\hline Fsa0730 & Umiak & Gozdanin, N-W & $\mathrm{B}$ & 29.11 & $\mathrm{ij}$ & 11.64 & cdefghi \\
\hline Fsa0731 & Hinga & Twierdzeń, N-W & $\mathrm{B}$ & 23.45 & defgh & 13.78 & $\mathrm{kl}$ \\
\hline Fsa0732 & Innowator & Słupsk, N & $\mathrm{R}$ & 22.78 & def & 12.69 & ghijkl \\
\hline Fsa0734 & Lord & Zamarte, N-W & B & 18.11 & bcd & 11.61 & cdefghi \\
\hline Fsa0736 & Kuba & Zamarte, N-W & $\mathrm{R}$ & 15.22 & $a b$ & 11.03 & cdef \\
\hline Fsa0737 & Bard & Mochełek, N-W & $\mathrm{R}$ & 12.44 & $\mathrm{a}$ & 10.35 & $\mathrm{bc}$ \\
\hline Fsa0738 & Rosalind & Mochełek, N-W & $\mathrm{R}$ & 26.89 & efghi & 11.22 & cdefg \\
\hline Fsa0740 & Korona & Mochełek, N-W & $\mathrm{R}$ & 28.44 & ghij & 13.17 & hijkl \\
\hline control & 1 & l & I & 9.22 & 1 & 1 & I \\
\hline mean & 1 & l & l & 24.99 & 1 & 11.94 & I \\
\hline mean for B & l & l & & 23.19 & l & 12.39 & l \\
\hline mean for $\mathrm{P}$ & 1 & l & & 30.22 & l & 11.31 & l \\
\hline mean for $\mathrm{R}$ & l & / & & 21.35 & l & 11.98 & l \\
\hline
\end{tabular}

Abbreviations and designations in table

a The first two digits in an isolate code indicate the year of isolation, the last two digits indicate the number of the isolate in the collection from a given year; ${ }^{\mathrm{b}} \mathrm{N}-\mathrm{W}$ - north-western Poland. C - central Poland. N-E - north-eastern Poland. S-E - south-eastern Poland. N - northern Poland; ${ }^{\mathrm{c}} \mathrm{B}$ - bright-beige, P - salmon pink, R - rose; ${ }^{\mathrm{d}}$ mean value of rot diameter and depth; ${ }^{\mathrm{e}}$ The homogeneous group obtained by comparing the mean values using LSD; ${ }^{\mathrm{f}}$ The mean growth per day calculated based on colony diameter measured after 3 and 6 days from the inoculation on PDA

were tubers inoculated with SNA medium disc without fungus. Tubers in plastic cuvettes were incubated in a growing chamber at $12-14{ }^{\circ} \mathrm{C}$, moisture $90-95 \%$ for 30 days. In the case of each tuber the diameter and depth of rot were measured in $\mathrm{mm}$. The mean value of those dimensions minus the mean value from the control samples were the basis for determining the pathogenicity of the isolates.
Statistical Analysis Applied in Pathogenicity and Petri Dish Tests

To compare the pathogenicity of isolates one-way analysis of variance (ANOVA) was applied. The calculations were made for the level of $\alpha=0.05$, in Matlab ver. 7.9 with the Statistics Toolbox. In the Petri dish tests the statistical analyses ANOVA 
or the nonparametric test of Kruskal-Wallis (KW) was carried out. The calculations were made for the level of $\alpha=0.05$, in Matlab ver. 7.9 program with Statistic Toolbox version 6.1. In the $\mathrm{KW}$ test, values were converted to ranks. In the case of significant differences Tukey's test was used to determine the least significant difference criterion LSD for $\alpha=0.05$. Chisquared test for $\alpha=0.05$ was applied to determine whether the occurrence of any of the three colors of mycelium is more probable. When analyzing the effect of the 4 control agents on MGI the statistical calculations were conducted additionally based on the average values calculated from the three concentrations (10, 50 and $100 \mathrm{ppm})$. Separate tests were performed for the two additional, higher, concentrations of GE.

To determine the relationships between the pathogenicity of isolates for the potato tubers and the growth on PDA and level of MGI by control agents, Pearson's correlation coefficient with a corresponding probability (if $p<0.05$ the correlation exists) was calculated.

\section{Extraction of DNA and General PCR Conditions}

DNA was extracted from 4-day-old mycelium grown on Potato Dextrose Broth (PDB; Difco, USA) according to the Cetyl Trimethyl Ammonium Bromide (CTAB) modified method of Doyle and Doyle (1990). DNA was diluted to $20 \mathrm{ng} \cdot \mu \mathrm{l}^{-1}$ in water and stored at $-20{ }^{\circ} \mathrm{C}$ until use.

Each $12.5 \mu \mathrm{l}$ PCR reaction contained $0.2 \mathrm{mM}$ of dNTPs, $1 \times$ buffer, $1 \times \mathrm{Q}$ solution, $1 \mathrm{mM} \mathrm{MgCl}_{2}, 0.5 \mathrm{U}$ of Taq DNA polymerase (PCR Core Kit QIAGEN, USA), 0.6 pM of each primer and $50 \mathrm{ng}$ of DNA. The amplification process involved an initial denaturation of $2 \mathrm{~min}$ at $95{ }^{\circ} \mathrm{C}$, followed by 30 or 35 cycles at $95{ }^{\circ} \mathrm{C}$ for $30 \mathrm{~s}$, annealing temperature and extension time specific for each assay, $72{ }^{\circ} \mathrm{C}$ for $1 \mathrm{~min}$, a final extension at $72{ }^{\circ} \mathrm{C}$ for $5 \mathrm{~min}$, and a $4{ }^{\circ} \mathrm{C}$ hold. The amplified PCR products were electrophoresed on $1.4 \%$ agarose gel with a TBE running buffer stained with ethidium bromide. A molecular marker of $100 \mathrm{bp}$ (EURx, Poland) was used. The results were scanned into a computer imaging file with a gel documentation system with a digital camera (INTAS, Germany).

Species Identification and Determination of Potential Mycotoxigenic Ability in PCR Assays

To confirm microscopic identification of F. sambucinum, the species-specific primer pair FSF1/FSR1 was used (Mishra et al. 2003). Additionally, ITS region and partial translation elongation factor 1-alpha (TEF) sequence were analyzed. The primer pair ITS1/ITS4 (White et al. 1990) was used for the amplification of ITS regions containing the 5.8S rDNA. The efl/ef2 (Geiser et al. 2004) and efl'/ef2' (Du et al. 2012) were used for amplification of the TEF gene region. As a control, in TEF assay, different Fusarium species such as F. avenaceum
(2 isolates), F. culmorum (4), F. equiseti (1), F. garminearum (2), F. langsethiae (2), F. oxysporum (2), F. poae (1) F. solani (3) and $F$. sporotrichioides (1) originated from different plants, from our own collection, were used. The PCR products amplified with these three primer pairs were sequenced (Genomed, Poland). Sequence comparisons were carried out using BLASTn (http://www.ncbi.nlm.nih.gov/BLAST). The potential ability to produce trichothecenes was tested using primers specific for the gene Tri5 and for the gene Tri4 that determines production of A-type trichothecenes (Nicholson et al. 2004). Sequences of all primers (IBB PAN, Poland), product sizes, annealing temperature and extension time for each assay are presented in Table 2.

\section{Results}

Reaction to Control Agents, Growth and Color of Mycelium on PDA

Isolates showed differentiated reactions to 4 control agents and their concentrations (Table 3).

Significant differences in their effect on MGI were found, $p=0$ (Table 4 A). Effectiveness in MGI was observed especially in the case of $\mathrm{M}$, but also with GE and $\mathrm{C}$. The lowest MGI was caused by CO. In the case of the 10 ppm concentration, $\mathrm{M}$ suppressed the growth of mycelium by $36.1 \%$, GE by $28.7 \%$, while $\mathrm{C}$ only by $9.7 \%$ and $\mathrm{CO}$ by $4.5 \%$. The differences in the mean effect of the control agents and their concentrations are shown in Fig. 1. Increasing the concentration of $\mathrm{C}$ resulted in raising its efficacy in comparison to GE. The most significant increase of MGI, from 9.7 to $52.1 \%$, was observed after increasing $\mathrm{C}$ concentration from $10 \mathrm{ppm}$ to $50 \mathrm{ppm}$. Further increasing to $100 \mathrm{pm}$ did not cause significantly greater inhibition. A similar result was also observed for M (Table 3).

In some cases more intensive growth of the fungus was observed (negative MGI) in comparison to the control on a medium with the addition of a control agent. Generally, the lowest concentration of each substance caused significantly weaker MGI in comparison to higher concentrations of each control agent. The exception was CO. Although no significant differences between efficacy of the three concentrations of $\mathrm{CO}$ were found, some trends were noticed: the concentration of $50 \mathrm{ppm}$ inhibited the mycelium growth at the weakest level in comparison to 10 and $100 \mathrm{ppm}$. In some cases the inhibition effect of $\mathrm{CO}$ was the strongest on plates with the lowest concentration (e.g. for Fsa0526 or Fsa0731). CO, regardless of concentration, only slightly affected MGI. Even the highest (100 ppm) concentration of CO in five isolates either did not cause growth inhibition or even promoted growth (e.g. Fsa0734) (Table 3). 
Table 2 Details of amplification conditions including sequences of primers, annealing temperature, extension time and cycle number

\begin{tabular}{|c|c|c|c|c|}
\hline Target & Primers & Sequence $5^{\prime} \rightarrow 3^{\prime}$ & PCR conditions & Product size (bp) \\
\hline F. sambucinum & FSF1/FSR1 & $\begin{array}{l}\text { ACATACCTTTATGTTGCCTCG } \\
\text { GGAGTGTCAGACGACAGCT }\end{array}$ & $58^{\circ} \mathrm{C}, 30 \mathrm{~s}, 30$ cycles & 315 \\
\hline TEF & ef1/ef2 & $\begin{array}{l}\text { ATGGGTAAGGA(A/G)GACAAGAC } \\
\text { GGA(G/A)GTACCAGT(G/C)ATCATGTT }\end{array}$ & $53{ }^{\circ} \mathrm{C}, 55 \mathrm{~s}, 30$ cycles & $\sim 700$ \\
\hline TEF & ef1'/ef2' & $\begin{array}{l}\text { ATGGGTAAGGAAGACAAGAC } \\
\text { GGAGGTACCAGTGATCATGTT }\end{array}$ & $58{ }^{\circ} \mathrm{C}, 55 \mathrm{~s}, 30$ cycles & $\sim 700$ \\
\hline ITS & ITS1/ITS4 & $\begin{array}{l}\text { TCCGTAGGTGAACCTGCGG } \\
\text { TCCTCCGCTTATTGATATGC }\end{array}$ & $52{ }^{\circ} \mathrm{C}, 50 \mathrm{~s}, 35$ cycles & $\sim 550$ \\
\hline Tri5 & Tri5F/Tri5R & $\begin{array}{l}\text { AGCGACTACAGGCTTCCCTC } \\
\text { AAACCATCCAGTTCTCCATCTG }\end{array}$ & $60{ }^{\circ} \mathrm{C}, 30 \mathrm{~s}, 30$ cycles & 545 \\
\hline Tri4 & T4F1506/T4EndR2 & $\begin{array}{l}\text { CCCCTGGCTACTCTCGAGA } \\
\text { AAGCTTTGAGAACCTTCAC }\end{array}$ & $54{ }^{\circ} \mathrm{C}, 30 \mathrm{~s}, 30$ cycles & 550 \\
\hline
\end{tabular}

Use of the $330 \mathrm{ppm}$ concentration generally, with the exception of 4 isolates, resulted in an increase of MGI with a $100 \%$ of MGI being observed for 3 isolates. The concentration of $500 \mathrm{ppm}$ increased mean MGI and $100 \%$ of MGI was noted for 8 isolates. Only isolate Fsa0737 did not react positively to an increase in the concentration of GE above 100 ppm (Table 3).

Individual isolates showed significantly $(p=0)$ different susceptibility to specific substances (Table 3; Table 4 B,C,D; Fig. 2,3,4). Some isolates were more strongly inhibited by the lowest concentration of GE than by chemical (synthetic) substances at the same concentration e.g. Fsa0551, Fsa0528, Fsa0555, Fsa0718 or Fsa0732. Most of the isolates were inhibited slightly more strongly by $\mathrm{M}$ than by $\mathrm{C}$. For some isolates (Fsa0530 and Fsa0734) C was more effective, excluding the concentration of $10 \mathrm{ppm}$, which generally only weakly inhibited growth of all the isolates. An interesting reaction was shown by isolate Fsa0734: concentration of $10 \mathrm{ppm}$ of $\mathrm{C}$ caused its stronger growth, than on the medium without the control agents $(-14.8 \%)$, while the further increasing to 50 and $100 \mathrm{ppm}$ resulted in a strong inhibition that was similar to the reaction of the other isolates. This isolate also grew the most intensively on the medium with the addition of any concentration of $\mathrm{CO}$ (Table 3).

Based on observation of mycelium on the control plates the isolates were divided into three color groups. Bright-beige (B) group was dominant (12 isolates $-42.9 \%$ ), 9 isolates were salmon pink (P) and 7 rose (R). However, Chi-squared test showed that there was no color significantly predominant. In the isolates from 2007 the red color of mycelium was predominant and all red isolates were collected in this year.

The significant differences in mycelium growth rate on PDA between the 28 isolates were shown in an ANOVA test. Growth rate varied from $8.6 \mathrm{~mm}$ (Fsa0530) to $13.9 \mathrm{~mm}$ (Fsa0718), with a mean value of $11.9 \mathrm{~mm}$. These two isolates formed two distinct homogeneous groups, respectively $a$ and $l$. The rest of the isolates were assigned to intermediate groups between those two. The ANOVA test also showed that the 3 different color groups of isolates grew significantly differently. B, R and P colonies formed three homogeneous groups, respectively $a, a b$ and $b$. The $\mathrm{P}$ colonies, which caused the greatest tuber damage, grew the slowest (Table 1, Table 4 E, F).

Isolates of a different color of mycelium showed different sensitivity to the control agents (Table 3, Table 4 G, Fig. 5). Significant differences were found in reaction to $M$, where $R$ isolates were more strongly inhibited than $\mathrm{P}$ and $\mathrm{B}$ isolates. Simultaneously $\mathrm{R}$ isolates were the most resistant to $\mathrm{C}$ and GE. Isolates of B group, compared with groups $\mathrm{P}$ and R, reacted much less to $\mathrm{CO}$.

When considering the five concentrations of GE, significant differences in the MGI were noted. $\mathrm{P}$ was inhibited most strongly, and $\mathrm{R}$ the least. With increasing concentration of GE (from $10 \mathrm{ppm}$ to $500 \mathrm{ppm}$ ) $\mathrm{P}$ and $\mathrm{B}$ isolates were increasingly inhibited, while the $\mathrm{R}$ isolates did not show any further increase of growth inhibition with concentrations greater than $100 \mathrm{ppm}$. Increasing the GE concentration to $500 \mathrm{ppm}$ resulted in mean MGI for P isolates at the level of $97 \%$ (Table 3).

\section{Pathogenicity Test}

All isolates were pathogenic to potato tubers cv. Bard and significant differences in pathogenicity were revealed, $p=0$. Mean size of tuber damage was $25 \mathrm{~mm}$, ranging from $10.6 \mathrm{~mm}$ (Fsa0726) to $78.9 \mathrm{~mm}$ (Fsa0543). These two isolates formed two distinct homogeneous groups, respectively $a$ and $k$. Others isolates were assigned to intermediate groups. Some differences in the pathogenicity of isolates differing in color were noted, but the KW test showed that they were not statistically significant $(p=0.176)$ (Table 1$)$.

Based on the Pearson correlation coefficient it was found that there was a correlation between pathogenicity for potato tubers and MGI on PDA for the highest GE concentration $(500 \mathrm{ppm})$. The correlation coefficient was 
Table 3 Mycelium growth inhibition (MGI) by control agents on PDA in Petri dishes experiment [\%]

\begin{tabular}{|c|c|c|c|c|c|c|c|c|c|c|c|c|c|c|}
\hline \multirow[t]{2}{*}{ Code of isolate } & \multicolumn{3}{|c|}{ Mancozeb } & \multicolumn{3}{|l|}{ Captan } & \multicolumn{3}{|c|}{ Copper oxychloride } & \multicolumn{5}{|c|}{ Grapefruit extract } \\
\hline & $10^{\mathrm{a}}$ & 50 & 100 & 10 & 50 & 100 & 10 & 50 & 100 & 10 & 50 & 100 & 330 & 500 \\
\hline $\mathrm{Fsa} 0525$ & $47.5^{\mathrm{b}}$ & 60.1 & 63.7 & 6.4 & 56.6 & 61.0 & 4.1 & 2.0 & 14.9 & 30.0 & 38.0 & 49.0 & 66.1 & 69.8 \\
\hline Fsa0526 & 47.0 & 60.3 & 62.5 & 8.5 & 55.5 & 58.9 & 17.6 & 7.1 & 11.1 & 30.8 & 50.5 & 58.7 & 72.2 & 78.1 \\
\hline Fsa0528 & 9.9 & 58.1 & 64.5 & 11.8 & 52.2 & 51.8 & -6.6 & -3.8 & 0.1 & 28.8 & 58.3 & 65.5 & 70.8 & 73.5 \\
\hline Fsa0530 & 26.4 & 39.0 & 46.5 & 13.9 & 62.2 & 66.0 & 1.1 & -11.2 & -16.5 & 28.6 & 42.3 & 45.0 & 90.0 & 90.0 \\
\hline Fsa0539 & 18.7 & 56.9 & 63.5 & 0.6 & 48.6 & 47.8 & -9.3 & -11.4 & -2.8 & 23.0 & 61.9 & 68.4 & 64.8 & 70.5 \\
\hline Fsa0540 & 47.2 & 57.9 & 59.7 & 13.6 & 52.5 & 56.6 & -11.2 & 9.0 & 14.0 & 39.1 & 35.4 & 50.4 & 70.1 & 100 \\
\hline Fsa0542 & 27.9 & 53.9 & 57.1 & 2.8 & 52.7 & 57.2 & 1.1 & 8.6 & 2.4 & 30.4 & 47.9 & 56.8 & 100 & 100 \\
\hline Fsa0543 & 45.7 & 54.6 & 56.1 & 10.0 & 59.3 & 58.8 & 11.7 & 5.7 & 19.0 & 29.3 & 57.8 & 56.1 & 78.4 & 100 \\
\hline Fsa0551 & 22.4 & 54.0 & 56.2 & 12.3 & 54.8 & 64.0 & -1.5 & 6.4 & 5.7 & 37.6 & 54.8 & 63.4 & 100 & 100 \\
\hline Fsa0552 & 47.2 & 59.0 & 58.6 & 19.7 & 64.4 & 66.0 & 24.7 & 17.3 & 30.3 & 31.7 & 55.9 & 61.1 & 92.5 & 100 \\
\hline Fsa0553 & 51.3 & 57.1 & 57.0 & 16.8 & 56.0 & 62.4 & 24.3 & 14.8 & 25.3 & 34.6 & 44.6 & 56.1 & 79.8 & 100 \\
\hline Fsa0555 & 16.2 & 58.3 & 68.6 & 14.4 & 55.1 & 57.3 & -1.0 & 8.1 & 6.9 & 33.9 & 44.7 & 49.2 & 73.7 & 78.9 \\
\hline Fsa0557 & 41.3 & 61.1 & 69.8 & 17.2 & 64.4 & 67.8 & 22.4 & -3.9 & 21.1 & 33.1 & 41.3 & 51.4 & 70.5 & 74.8 \\
\hline Fsa0637 & 44.5 & 54.6 & 53.4 & 7.6 & 53.8 & 54.2 & -0.4 & 1.3 & 3.7 & 26.5 & 43.0 & 50.2 & 71.7 & 100 \\
\hline Fsa0709 & 38.6 & 66.3 & 62.1 & 6.8 & 56.2 & 57.8 & 14.0 & -0.4 & 10.1 & 32.0 & 39.7 & 51.0 & 68.9 & 76.0 \\
\hline Fsa0718 & 5.6 & 34.1 & 38.2 & 7.0 & 42.3 & 31.9 & -0.2 & -8.6 & -15.4 & 30.0 & 43.1 & 50.0 & 54.1 & 57.5 \\
\hline Fsa0719 & 45.9 & 49.9 & 53.2 & 3.9 & 50.5 & 56.6 & -2.3 & 1.3 & 12.9 & 34.9 & 40.9 & 49.1 & 100 & 100 \\
\hline Fsa0720 & 47.4 & 66.1 & 68.8 & 5.0 & 52.8 & 56.2 & 14.1 & 6.5 & 15.7 & 26.4 & 43.6 & 50.3 & 53.3 & 56.5 \\
\hline Fsa0726 & 38.5 & 45.6 & 49.3 & 24.9 & 52.9 & 58.1 & -14.6 & -7.9 & -6.8 & 39.4 & 40.0 & 46.3 & 59.5 & 57.2 \\
\hline Fsa0727 & 47.3 & 64.8 & 67.6 & 11.0 & 45.9 & 49.4 & 1.7 & 6.0 & 6.3 & 20.8 & 58.2 & 62.1 & 59.2 & 61.5 \\
\hline Fsa0730 & 39.5 & 54.2 & 62.8 & 8.0 & 38.6 & 42.2 & 3.5 & 0.0 & 9.1 & 24.5 & 30.6 & 38.0 & 57.8 & 63.6 \\
\hline Fsa0731 & 40.4 & 64.8 & 66.6 & 8.5 & 48.7 & 57.3 & 20.7 & 14.2 & 12.9 & 19.8 & 55.7 & 70.9 & 52.3 & 59.3 \\
\hline $\mathrm{Fsa} 0732$ & 7.1 & 63.3 & 65.4 & 5.3 & 47.0 & 50.1 & 1.1 & 3.6 & 15.4 & 26.2 & 43.0 & 48.4 & 56.8 & 58.3 \\
\hline Fsa0734 & 15.7 & 13.2 & 23.6 & -14.8 & 50.7 & 54.2 & -22.7 & -17.7 & -31.6 & 12.6 & 33.0 & 35.6 & 72.0 & 75.9 \\
\hline Fsa0736 & 54.1 & 64.3 & 68.5 & 15.1 & 46.6 & 46.9 & -5.7 & -4.2 & 4.1 & 12.7 & 27.2 & 40.6 & 47.8 & 47.7 \\
\hline Fsa0737 & 45.4 & 59.7 & 62.6 & 10.5 & 45.8 & 49.8 & 7.3 & 9.0 & 0.1 & 32.6 & 50.9 & 56.6 & 52.2 & 50.1 \\
\hline Fsa0738 & 34.7 & 54.7 & 60.5 & 9.5 & 39.3 & 44.1 & 10.1 & 4.8 & 4.8 & 29.4 & 40.4 & 46.4 & 55.6 & 54.5 \\
\hline Fsa0740 & 56.3 & 69.1 & 73.8 & 15.5 & 52.5 & 57.7 & 21.5 & 5.1 & 19.5 & 25.7 & 38.8 & 44.1 & 65.0 & 64.5 \\
\hline mean & 36.1 & 55.5 & 59.3 & 9.7 & 52.1 & 55.1 & 4.5 & 2.2 & 6.9 & 28.7 & 45.1 & 52.5 & 69.8 & 75.6 \\
\hline mean for $\mathrm{B}$ & 31.3 & 51.2 & 56.4 & 8.5 & 52.6 & 55.0 & 3.0 & -2.5 & 1.1 & 28.1 & 43.4 & 51.1 & 66.8 & 71.0 \\
\hline mean for $\mathrm{P}$ & 38.0 & 55.5 & 57.3 & 10.9 & 55.1 & 58.6 & 4.4 & 6.7 & 12.6 & 32.5 & 48.7 & 56.5 & 84.8 & 97.1 \\
\hline mean for $\mathrm{R}$ & 41.7 & 63.1 & 66.7 & 10.3 & 47.1 & 50.6 & 7.2 & 4.4 & 9.4 & 24.8 & 43.2 & 49.8 & 55.7 & 56.1 \\
\hline
\end{tabular}

${ }^{\mathrm{a}}$ concentration of the substance in ppm, ${ }^{\mathrm{b}}$ mean value of 3 replications

Abbreviations and designations in table: B - bright-beige mycelium, $\mathrm{P}$ - salmon pink mycelium, R - rose mycelium

$0.413(p=0.029)$. This means that the higher the pathogenicity of an isolate (measured by the growth on potato tubers), the greater the MGI of this isolate for this concentration of GE. There was no correlation between pathogenicity for potato tubers and growth of isolates on PDA. The correlation coefficient was 0.077 $(p=0.697)$. Some isolates growing very strongly on the PDA did not cause severe damage to tubers. The most pathogenic isolate Fsa0543, which caused damage to the tubers at the level of $78.89 \mathrm{~mm}$ in the medium reached a diameter of $12.03 \mathrm{~cm}$, while isolate Fsa0718, which caused damage of the tubers of only $22.11 \mathrm{~mm}$ grew the most and reached $13.92 \mathrm{~mm}$ on PDA medium.

\section{PCR Assay}

PCR assay with species specific primers FSF1/FSR1 confirmed microscopic analysis. In the case of all 28 isolates product of $315 \mathrm{bp}$ was obtained.

NCBI Blast analysis of the 674 - bp segment of tefl gene and the 534 - bp segment of ITS region also confirmed the species of F. sambucinum. Sequences of three isolates 
Table 4 Summary of ANOVA and Kruskal-Wallis (KW) analyses for 28 isolates of F. sambucinum

\begin{tabular}{lllll}
\hline Source of variation & SS & df & MS & $\begin{array}{l}\text { F (ANOVA)/ } \\
\text { Chi-sq (KW) }\end{array}$
\end{tabular}$\quad$ Prob >chi-sq

$\begin{array}{llllll}\text { A. Mean effect of } 4 \text { control agent and their concentrations on MGI (KW) (Fig. 1) } \\ \text { Groups } & 5.1755 \mathrm{e}+008 & 11 & 47049965.1 & 1527.36 & 0 \\ \text { Error } & 1.65238 \mathrm{e}+008 & 2004 & 82453.9 & & \\ \text { Total } & 6.82787 \mathrm{e}+008 & 2015 & & & \end{array}$

B. Effect of 10 ppm concentrations of control agents on MGI of individual isolate on PDA (KW) (Fig. 2)

$\begin{array}{llllll}\text { Groups } & 2.14892 \mathrm{e}+007 & 111 & 193,596 & 570.21 & 0 \\ \text { Error } & 3.79849 \mathrm{e}+006 & 560 & 6,783 & & \\ \text { Total } & 2.52876 \mathrm{e}+007 & 671 & & & \end{array}$

C. Effect of $50 \mathrm{ppm}$ concentrations of control agents on MGI of individual isolate on PDA (KW) (Fig. 3)

$\begin{array}{llllll}\text { Groups } & 2.27992 \mathrm{e}+007 & 111 & 205398.1 & 604.96 & 0 \\ \text { Error } & 2.48897 \mathrm{e}+006 & 560 & 4444.6 & & \\ \text { Total } & 2.52882 \mathrm{e}+007 & 671 & & & \end{array}$

D. Effect of 100 ppm concentrations of control agents on MGI of individual isolate on PDA (KW) (Fig. 4)

$\begin{array}{llllll}\text { Groups } & 2.13422 \mathrm{e}+007 & 111 & 192,272 & 566.29 & 0 \\ \text { Error } & 3.94625 \mathrm{e}+006 & 560 & 7046.9 & & \\ \text { Total } & 2.52884 \mathrm{e}+007 & 671 & & & \end{array}$

E. Mycelium growth on PDA (ANOVA) (Table 1)

$\begin{array}{llllll}\mathrm{X} 1 & 314.839 & 27 & 11.6607 & 5.68 & 2.48745 \mathrm{e}-012 \\ \text { Error } & 287.56 & 140 & 2.054 & & \\ \text { Total } & 602.399 & 167 & & & \end{array}$

F. Mycelium growth on PDA in respect to mycelium color (ANOVA) (Table 1)

$\begin{array}{llllll}\text { X1 } & 35.938 & 2 & 17.969 & 5.23 & 0.0063 \\ \text { Error } & 566.461 & 165 & 3.4331 & & \\ \text { Total } & 602.399 & 167 & & & \\ \text { Gean effect of control agents on MGI } & \text { in } & \text { respect } & & & \\ \text { Groups } & 3.29607 \mathrm{e}+008 & 11 & 29964267.1 & 972.72 & 0 \\ \text { Error } & 3.5318 \mathrm{e}+008 & 2004 & 176237.6 & & \\ \text { Total } & 6.82787 \mathrm{e}+008 & 2015 & & & \\ & & & \end{array}$

differing in the color of mycelium were deposited in GenBank with Accession No. KC899118 - KC899120 for Tefl $\alpha$ gene and KC899115 - KC899117 for ITS regions.

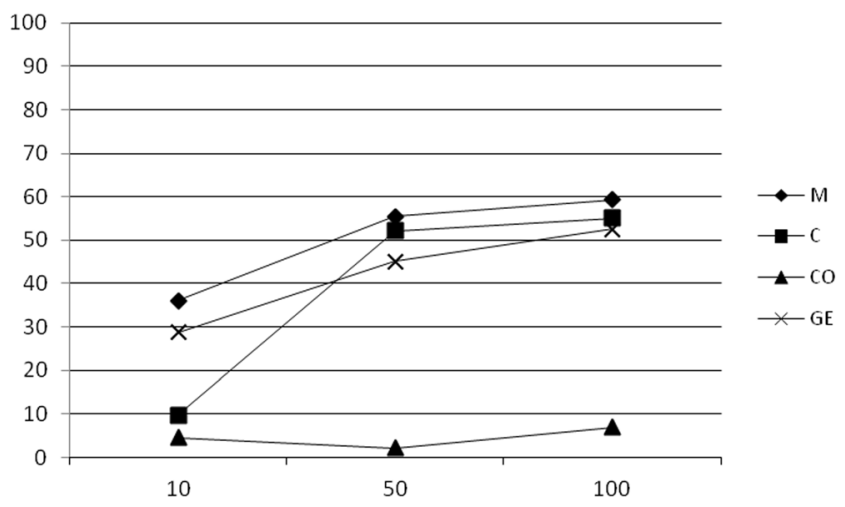

Fig. 1 Effect of 10, 50 and 100 ppm concentrations of Mancozeb, Captan, Copper oxychloride and Grapefruit extract on mycelium growth inhibition on PDA [\%]
Analysis of the TEF PCR product generated using the efl/ ef2 primers showed a difference in the sequences of isolates differing in color. There was one single nucleotide polymorphism (SNP) between the sequences of the groups of isolates. It was located at position 390 (transition $\mathrm{C} \leftrightarrow \mathrm{T}$ ) of the amplicon. In the case of the $\mathrm{B}$ and $\mathrm{P}$ isolates thymine was identified, while cytosine was found in R isolates (Fig. 6).

Products with efl/ef2 primers were obtained not only for F. sambucinum, but also for all control samples from Fusarium spp. The use of efl'/ef2' primers resulted in product being obtained for a smaller number of control isolates. It resulted in product presence for $F$. poae, but not for all isolates of $F$. solani, $F$. oxysporum and $F$. langsethiae. Product was missing for $F$. avenaceum, F. culmorum, F. eqiuseti, F. graminearum and $F$. sporotrichioides. Sequence of the ITS regions were identical for all DNA samples regardless of their color.

Tri5 and Tri4 genes were present in all isolates, which shows their potential ability to produce A-type trichothecenes. HPLC analyses of randomly chosen potato tubers infected 
Fig. 2 Effect of $10 \mathrm{ppm}$ concentrations of Mancozeb, Captan, Copper oxychloride and Grapefruit extract on mycelium growth inhibition of single isolate on PDA [\%]

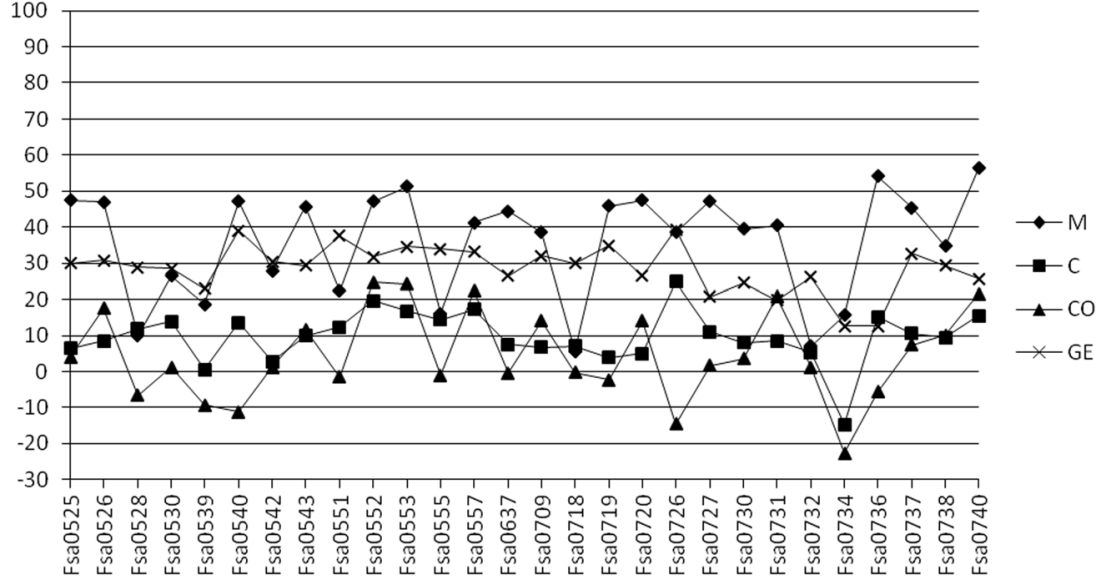

with different isolates in pathogenicity test showed the presence of monoacetoxyscirpenol (MAS) and diacetoxyscirpenol (DAS) in their tissues. Concentration of mycotoxins was not associated with the size of the tuber rot (data not presented).

\section{Discussion}

According to the literature the precise classification of isolates of Fusarium spp. causing dry rot of potato tubers has been problematic. The treatment of $F$. sambucinum, one of the causal agent of the disease, differs depending upon the authority (Leslie and Summerell 2006) because of contradictory classification systems proposed by various researchers e.g. Booth (1971), (Gerlach and H. Nirenberg 1982), Nelson et al. (1983) and Nirenberg (1995) that are primarily based on morphological characters of the colonies. For instance (Nelson et al. 1983) included F. sulphureum and other forms in a broad species concept of $F$. sambucinum sensu lato. Nirenberg (1995) divided F. sambucinum sensu lato into three taxa: $F$. sambucinum Fuckel sensu stricto, $F$. venenatum Nirenb. and F. torulosum (Berk. \& Curt.) Nirenb. RAPD assays of Yoder and Christianson (1998) support Nirenberg's contention that the three species are indeed distinct. Leslie and Summerell (2006) noted they can be confused because of their very similar morphology. Molecular methods have greatly facilitated identification of the species. Species specific primers (Mishra et al. 2003) allowed for a clear identification of our isolates and classified them into F. sambucinum.

Sequencing of ITS as well TEF regions confirmed SCARPCR assay. ITS regions are commonly used for identification of Fusaria (Tan and Niessen 2003; Wilson et al. 2004). Sometimes clear identification is not possible due to the fact that some species have identical sequences of some ITS regions, e.g. six species analyzed by Waalwijk et al. (1996) had identical ITS1 sequences. However, O’Donnell (1992) noted that the rDNA genic regions are highly conserved within $F$. sambucinum, which probably in the case of this species allowed him to obtain a reliable result. Schoch et al. (2012) evaluated six DNA regions as potential DNA barcodes for Fungi. They concluded that the ITS region has the highest probability of successful identification for the broadest range of fungi, with the most clearly defined barcode gap between inter- and intraspecific variation. NCBI Blast analysis of ITS regions of our isolates clearly showed the species F. sambucinum, because of the highest level of identity with
Fig. 3 Effect of $50 \mathrm{ppm}$ concentrations of Mancozeb, Captan, Copper oxychloride and Grapefruit extract on mycelium growth inhibition of single isolate on PDA [\%]

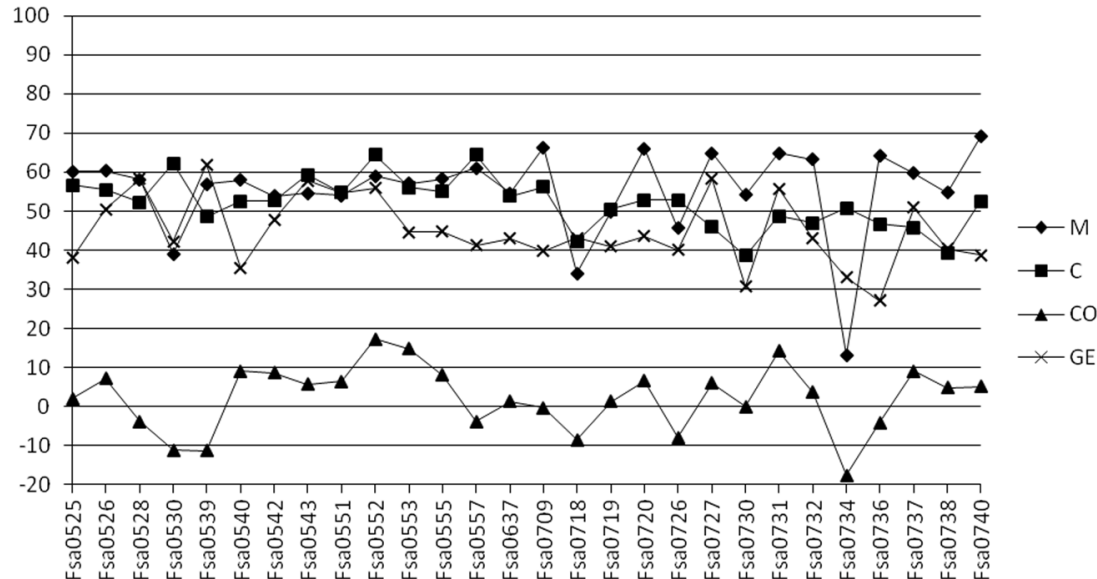


Fig. 4 Effect of $100 \mathrm{ppm}$ concentrations of Mancozeb, Captan, Copper oxychloride and Grapefruit extract on mycelium growth inhibition of single isolate on PDA [\%]

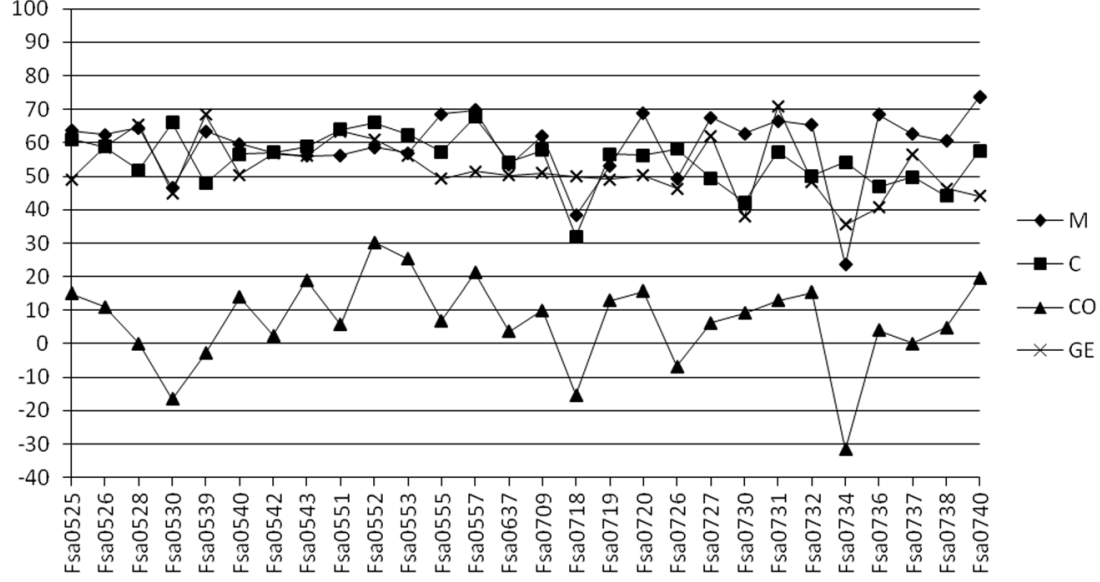

isolates described and deposited in GenBank e.g. by (O'Donnell 1992) and Hatsch et al. (2004). Also, Wharton et al. (2006) based on the sequences of the ITS region identified isolates of $F$. sambucinum causing potato tuber sprout rot.

Due to the fact that many Fusaria within the Gibberella clade possess non-orthologous copies of the ITS2, which can lead to incorrect phylogenetic inferences (O'Donnell and Cigelnik 1997; O’Donnell et al. 1998) in many cases analysis of the translation elongation factor 1- $a$ (TEF) gene is applied. TEF encodes an essential part of the protein translation machinery and has high phylogenetic utility because it is highly informative at the species level in Fusarium. Non-orthologous copies of the gene have not been detected in the genus and universal primers have been designed that work across the phylogenetic breadth of the genus (Geiser et al. 2004). PCR assays with universal primers efl/ef2 and ef1'/ef2' that amplify TEF sequences allowed us to obtain the product with many species of Fusarium. (Geiser et al. 2004) using the efl/ and ef2 primers generated products with numerous Fusarium species, including all isolates applied as control samples in our studies, and created FUSARIUMID v. 1.0 database of partial translation elongation factor 1-alpha (TEF) DNA sequences.

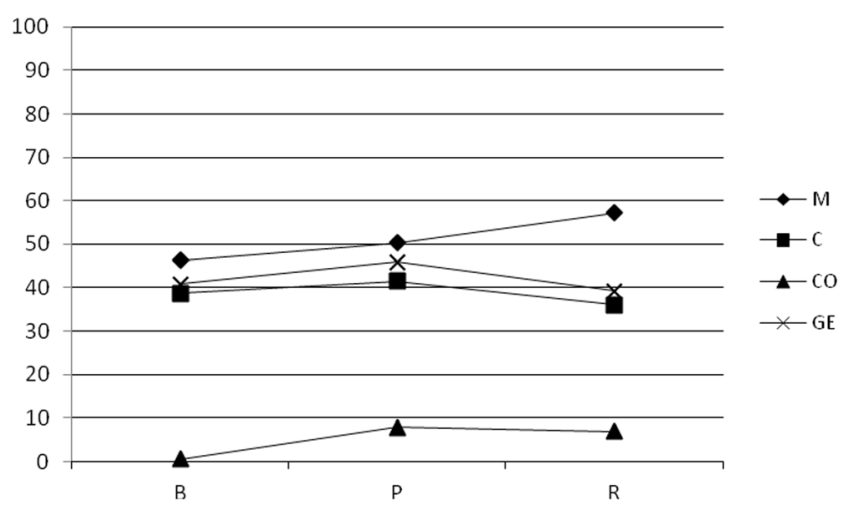

Fig. 5 Mean effect of three concentrations (10, 50 and $100 \mathrm{ppm}$ ) of Mancozeb, Captan, Copper oxychloride and Grapefruit extract on mycelium growth inhibition in respect to mycelium color (B - bright-beige, $\mathrm{P}$ salmon pink and $\mathrm{R}$ - rose) [\%]
The use of primers ef1'/ef2' (Du et al. 2012) reduced the Fusarium species for which the product was obtained. Unlike our results, (Du et al. 2012) obtained amplicons e.g. for $F$. avenaceum and $F$. equiseti. Since amplicons of different species of Fusarium are obtainable with these primer pairs, it is not possible to identify the species of $F$. sambucinum based only on the presence of the product (band) and only sequence analysis allows for the identification of the species. The sequence of our $\mathrm{R}$ isolates was identical with $F$. sambucinum sequences AJ543602- AJ543605 (Kristensen et al. 2005) and $\mathrm{B}$ and P differ only with SNP. Differences between our sequences and the sequences of $F$. torulosum and $F$. venenatum were much higher.

Differences in TEF gene sequence for one single nucleotide polymorphism were found between our isolates differing in color. Wollenweber and Reinking (1935) distinguished several forms of $F$. sambucinum based primarily on colony color and other morphological traits. According to Booth (1971) pigmentation of mycelium is often characteristic for different forms and species and could be an important feature used to distinguish them. He considered F. sambucinum to be a few distinct species including $F$. sambucinum represented by the red cultures, F. sulphureum the yellowish and F. trichothecioides the rose colored, pionnotal ones. However, the color of mycelium does not differentiate between the species most commonly confused with $F$ sambucinum sensu stricto, ie $F$. torulosum and $F$. venenatum (Desjardins and Beremand 1987; Logrieco et al. 1995). Our studies agree with these observations of the mentioned authors who noted isolates of different pigment (red, yellow, rose, brown) within the same species, F. sambucinum sensu stricto. Also, mycelium of F. torulosum can be red brownish or beige (Logrieco et al. 1995).

Mycotoxin profiles can also be useful in Fusarium spp. identification (Altomare et al. 1995; Logrieco et al. 1995; Thrane and Hansen 1995). Desjardins and Plattner (1989) revealed that production of trichothecene toxins is a common trait of G. pulicaris strains isolated from potato tuber dry-rot. 
Fsa0553-P: 361 CCCGCCACTT GAGCGACATG CCCTTCCTCT AAAGCCACGG GCGCGCATCA TCACGTGTTG 420

Fsa0737-R: 361 CCCGCCACTT GAGCGACATG CCCTTCCTCC AAAGCCACGG GCGCGCATCA TCACGTGTTG 420

Fsa0555-B: 361 CCCGCCACTT GAGCGACATG CCCTTCCTCT AAAGCCACGG GCGCGCATCA TCACGTGTTG 420

Fig. 6 Alignment of Tefl $\alpha$ gene regions for the isolates differ in color of mycelium

They, as well as (El-Banna et al. 1984), found that trichothecenes were formed in potato tubers infected with F. sambucinum. Jelen et al. (1995) and Ellner (2002) detected A-type trichothecenes (e.g. DAS, MAS) in all potato tubers inoculated with F. sambucinum. The detection of Tri5 and Tri4 genes indicated the ability of our isolates to produce trichothecenes, which was confirmed in our studies by randomly carried out HPLC analyses (data not published). Hohn and Desjardins (1992) detected and identified the Tri5 gene in F. sambucinum. This gene initiates the trichothecene biosynthetic pathway. Edwards et al. (2001) and Nicholson et al. (2004) confirmed by PCR assay the ability of $F$. sambucinum to produce Type-A trichothecenes, which is related to gene Tri4. The presence of these substances in the tuber poses a threat not only to the plants, but mainly to the consumer, as these are some of the most toxic mycotoxins and are more acutely toxic than the B trichothecenes (Ueno 1983). Fusarium sambucinum is able to produce trichothecenes, unlike e.g. F. torulosum (Altomare et al. 1995). Molecular analyses showed that all of our isolates are genetically able to produce A-group trichothecenes, which therefore excludes the presence of F. torulosum, which is capable of producing moniliformin. Trichothecene production is related to pathogenicity (Desjardins and Hohn 1997; Wagacha and Muthomi 2007). Mycotoxins have been found in tuber tissues showing symptoms of tuber dry rot by Peters et al. (2008). For an evaluation of the pathogenicity of the isolates we measured, as Valluru et al. (2006), the diameter and depth of the lesions in the potato tuber. In many of the isolates analyzed in our experiment we observed extensive damage to potato tubers of cv. Bard. We also showed that all our isolates were pathogenic and that they varied in pathogenicity. It is consistent with observations of Desjardins and Hohn (1997) who revealed that pathogenicity of G. pulicaris can vary and also that the reaction of potato cultivars to different isolated can be variable. Isolates can range from highly pathogenic isolates to completely nonpathogenic isolates (El-Hassan et al. 2007). In addition to varying pathogenicity measured by the mycelium development in potato tubers, isolates differed in growth on PDA medium. No correlation between these parameters indicates that the measurement of the growth rate of the fungus on a medium containing an extract of potato tubers is not passed through to the development of the mycelium in the tuber and the related degree of pathogenicity to tubers.

In order to limit the development of fungi of the genus Fusarium, including F. sambucinum, on potato tubers various control agents have been used for many years, because no high level resistance to the pathogens exists among commercially grown cultivars (Bojanowski et al. 2013). Control of dry rot has been achieved primarily by applications of thiabendazole (TBZ) (Powelson et al. 1993; Secor and Gudmestad 1999). However, a tolerance and resistance of F. sambucinum strains to TBZ has been found (Desjardins et al. 1993; Gachango et al. 2012; Hanson et al. 1996).

Analyses of Bojanowski et al. (2013) have shown that different fungicides in varying degrees may control potato dry rot. Mancozeb, recommended for potato seed treatment, that has proven effective in the reduction of the pathogen after application on seed potato tubers (Cwalina-Ambroziak and Czajka 2006; Leach and Nielsen 1975), also limited the growth of our F. sambucinum isolates. Captan as well clearly inhibited the growth of $F$. sambucinum. Both preparations have also been found to be effective in reducing the severity of potato rot caused by $F$. solani and, as in our study, mancozeb was again somewhat more effective (Taskeen-Un et al. 2011). However, while captan effectively inhibited growth of our isolates at the higher concentrations, the use of the lowest concentration in the case of one of the isolates stimulated its growth, which suggests that excessive dose reduction may be even more dangerous than no use of the fungicide. Taskeen-Un et al. (2011) found that higher concentration of fungicides caused more reduction in the rot severity caused by $F$. solani than did lower concentrations. Similarly, in our Petri dish experiments, such an effect on $F$. sambucinum isolates was particularly evident in the case of increasing the concentration from 10 to $100 \mathrm{ppm}$.

The reaction of our isolates to control agents varied. Such differentiation was also observed by Daami-Remadi et al. (2006) and Choiseul et al. (2007) for various fungi causing dry tuber rots. They noted that the changes in isolate sensitivity to fungicides they recorded highlight the need for regular monitoring programs to be conducted in order that diseasecontrol strategies can remain effective

Bojanowski et al. (2013) also noted that apart from the use of fungicides, which has been the primary disease management practice in potato production (Hamm et al. 2008), several biological control agents were effective against F. sambucinum and could be used as an alternative to synthetic chemical compounds. The global trend appears to be shifting towards a reduced use of fungicides. There is a strong public and scientific desire to develop effective methods of controlling postharvest diseases that are perceived as safe by the public and pose reduced risk to human health and the environment (Mari et al. 2007; Wisniewski and Wilson 1992). To such eco-friendly control agents can be included, for example, citrus extracts that show an effective antimicrobial activity 
against foodborne pathogens including bacteria and fungi (Fisher and Phillips 2008). In Poland, the grapefruit extract 'Biosept' is approved for use in organic agricultural systems. It stimulates the resistance of plants and works as a fungicide (Orlikowski and Skrzypczak 2003). We observed its high efficacy in reducing the growth of $F$. sambucinum on PDA. It worked only slightly less well than mancozeb or Captan at comparable concentrations, and increasing the concentration to $500 \mathrm{ppm}$ in some cases definitely inhibited the growth of some isolates. Because of the lack of toxicity of this substance, it seems to be important to think about the potential control of F. sambucinum with grapefruit extract, including postharvest damage, especially since the salmon pink colonies, which caused the greatest tuber damage, were most strongly inhibited by Biosept. In agreement with our experiments with grapefruit extract, increasing the concentration of essential oil extracted from the epicarp of Citrus sinensis to a few hundred ppm significantly improved fungitoxicity against 10 postharvest pathogens of fruits (Sharma and Tripathi 2006). Bevilacqua et al. (2012) noted a reduction of F. oxysporum spores in pineapple juice after the application of citrus extract. Biosept greatly limited pathogens of barley in organic farming (Baturo 2009) and showed wide fungistatic activity in the control of leaf and soil-borne pathogens including Fusarium spp. (Orlikowski and Skrzypczak 2003; Patkowska 2006).

Apart from the grapefruit extract also copper products, including copper oxychloride, are applied in organic farms in Poland against e.g. potato blight (http 3- IOR). The Organic Farming Research Foundation organic farmer survey reported that copper is the second, after sulfur, most-applied disease control material on organic farms in the USA (Andrews and B. Baker 2013). Our studies revealed not only its ineffectiveness in inhibiting the growth of $F$. sambucinum, but that it can even stimulate the growth of the pathogen. This suggests that the use of this control agent against potato dry rot caused by this pathogen could be inefficient.

Open AccessThis article is distributed under the terms of the Creative Commons Attribution License which permits any use, distribution, and reproduction in any medium, provided the original author(s) and the source are credited.

\section{References}

Altomare, C., A. Logrieco, A. Bottalico, G. Mule, A. Moretti, and A. Evidente. 1995. Production of type A trichothecenes and enniatin B by Fusarium sambucinum Fuckel sensu lato. Mycopathologia 129: 177-181.

Andrews, N., and B. Baker. 2013. Can I use this product for disease management on my organic farm? http://www.extension.org/pages/ 18360/can-i-use-this-product-for-disease-management-on-myorganic-farm\#.UmwPUINN7VJ. Accessed 20 August 2013.

Baturo, A. 2009. Effect of biopreparations on the health of grain of spring barley (Hordeum vulgare) in organic system. Phytopathologia 53: 19-30.
Baturo-Ciesniewska, A., and M. Suchorzynska. 2011. Verification of the effectiveness of SCAR (sequence characterized amplified region) primers for the identification of Polish strains of Fusarium culmorum and their potential ability to produce B-trichothecenes and zearalenone. International Journal of Food Microbiology 148: 168-176.

Bevilacqua, A., D. Campaniello, M. Sinigaglia, C. Ciccarone, and M.R. Corbo. 2012. Sodium-benzoate and citrus extract increase the effect of homogenization towards spores of Fusarium oxysporum in pineapple juice. Food Control 28: 199-204.

Bojanowski, A., T.J. Avis, S. Pelletier, and R.J. Tweddell. 2013. Management of potato dry rot. Postharvest Biology and Technology 84: 99-109.

Booth, C. 1971. The Genus Fusarium. Commonwealth Mycological Institute, Kew, Surrey, United Kingdom

Boyd, A.E.W. 1972. Potato storage disease. Review of Plant Pathology 51: $297-321$

Chelkowski, J. 1989. Toxinogenicity of Fusarium species causing dry rot of potato tubers. In Fusarium mycotoxins, taxonomy and pathogenicity, ed. J. Chelkowski, 435-440. New York: Elsevier Publishing Co.

Choiseul, J., L. Allen, and S.F. Carnegie. 2007. Fungi causing dry tuber rots of seed potatoes in storage in Scotland. Potato Research 49: 241-253.

Cwalina-Ambroziak, B., and W. Czajka. 2006. Chemical control as a factor decreasing the infestation of potato tubers by pathogenic fungi. Progress in Plant Protection 46: 660-663.

Daami-Remadi, M., H. Jabnoun-Khiareddine, F. Ayed, and M. El Mahjoub. 2006. In vitro and in vivo interaction of four fungicides with the Fusarium species complex causing tuber dry rot in Tunisia. Plant Pathology Journal 5: 362-367.

Desjardins, A.E. 1995. Population structure of Gibberella pulicaris (anamorph Fusarium sambucinum) from potato tuber dry rot in North America and Europe. American Potato Journal 72: 145-156.

Desjardins, A.E., and M. Beremand. 1987. A genetic system for trichothecene toxin production in Gibberellapulicaris (Fusarium sambucinum). Phytopathology 77: 678-683.

Desjardins, A.E., and T.M. Hohn. 1997. Mycotoxins in plant pathogenesis. Molecular Plant-Microbe Interaction 10: 147-152.

Desjardins, A.E., and R.D. Plattner. 1989. Trichothecene toxin production by strains of Gibberella pulicaris (Fusarium sambucinum) in liquid culture and in potato tubers. Journal of Agricultural and Food Chemistry 37: 388-392.

Desjardins, A.K., E.A. Christ-Homed, S.P. McCormick, and G.A. Secor. 1993. Population structure and genetic analysis of field resistance to thiabendazole in Gibberella pulicaris from potato tubers. Phytopathology 83: 164-170.

Doyle, J.J., and J.L. Doyle. 1990. Isolation of plant DNA from fresh tissue. Focus 12: 13-15.

Du, M., X. Ren, Q. Sun, Y. Wang, and R. Zhang. 2012. Characterization of Fusarium spp. causing potato dry rot in China and susceptibility evaluation of Chinese potato germplasm to the pathogen. Potato Research 55: 175-184.

Edwards, S.G., S.R. Pirgozliev, M.C. Hare, and P. Jenkinson. 2001. Quantification of trichothecene-producing Fusarium species in harvested grain by competitive PCR to determine efficacies of fungicides against Fusarium head blight of winter wheat. Applied and Environmental Microbiology 67: 1575-1578.

El-Banna, A.A., P.M. Scott, P.Y. Lau, T. Sakuma, H.W. Platt, and V. Campbell. 1984. Formation of trichothecenes by Fusarium solani var. coeruleum and Fusarium sambucinum in potatoes. Applied and Environmental Microbiology 47: 1169-1171.

El-Hassan, K.I., M.G. El-Saman, A.A. Mosa, and M.H. Mostafa. 2007. Variation among Fusarium spp. the causal of potato tuber dry rot in their pathogenicity and mycotoxins production. Egyptian Journal of Phytopathology 35: 53-68.

Ellner, F.M. 2002. Mycotoxins in potato tubers infected by Fusarium sambucinum. Mycotoxin Research 18: 57-61. 
Fisher, K., and C. Phillips. 2008. Potential antimicrobial uses of essential oils in food: is citrus the answer? Trends in Food Science and Technology 19: 156-164.

Gachango, E., L.E. Hanson, A. Rojas, J.J. Hao, and W.W. Kirk. 2012. Fusarium spp. causing dry rot of seed potato tubers in Michigan and their sensitivity to fungicides. Plant Disease 96: 1767-1774.

Geiser, D.M., M. del Jimenez-Gasco, S. Kang, I. Makalowska, N. Veeraraghavan, T.J. Ward, et al. 2004. FUSARIUM-ID v. 1.0: a DNA sequence database for identifying Fusarium. European Journal of Plant Pathology 110: 473-479.

Gerlach, W., and H. Nirenberg. 1982. The genus Fusarium - A pictorial atlas. Mitteilungen aus der Biologischen Bundesanstalt Für Landund Forstwirtschaft (Berlin - Dahlem) 209: 1-405.

Hamm, P. B., R.A. Boyston, C.W. Hoy, R.W. Stevenson, and P.J.S. Hutchison. 2008. Applying pesticides. In D.A. Johnson (Ed.), Potato Health Management. The American Phytopathological Society, St. Paul. Mn, USA, pp. 113-121.

Hanson, L.E., S.J. Schwager, and R. Loria. 1996. Sensitivity to thiabendazole in Fusarium species associated with dry rot of potato. Phytopathology 86: 378-384.

Hatsch, D., V. Phalip, and J.M. Jeltsch. 2004. Use of genes encoding cellobiohydrolase-C and topoisomerase II as targets for phylogenetic analysis and identification of Fusarium. Research in Microbiology 155: 290-296.

Hohn, T.M., and A.E. Desjardins. 1992. Isolation and gene disruption of the Tox 5 geneencoding trichodiene synthase in Gibberella pulicaris. Molecular Plant-Microbe Interactions 5: $149-156$.

Hooker, W.J. 1981. Compendium of Potato Disease. Fusarium dry rots. American APS Press, St. Paul Minnesota, MN, pp. 58-60

http 1- Faostat 2012: http://faostat.fao.org/

http 2- Polish Central Statistical Office 2012: http://www.stat.gov.pl/gus

http 3- IOR: http://www.ior.poznan.pl/19,wykaz-sor-w-rolnictwieekologicznym.html

Jelen, H.H., C.J. Mirocha, E. Wąsowicz, and E. Kamiński. 1995. Production of volatile sesquiterpenes by Fusarium sambucinum strains with different abilities to synthesize trichothecenes. Applied and Environmental Microbiology 61: 3815-3820.

Kim, J.C., Y.W. Lee, and S.H. Yu. 1995. Sambutoxin-producing isolates of Fusarium species and occurrence of sambutoxin in rotten potato tubers. Applied and Environmental Microbiology 61: $3750-3751$.

Kristensen, R., M. Torp, B. Kosiak, and A. Holst-Jensen. 2005. Phylogeny and toxigenic potential is correlated in Fusarium species as revealed by partial translocation elongation factor $1 \alpha$ gene sequences. Mycological Research 109: 173-186.

Leach, S.S., and L.W. Nielsen. 1975. Elimination of fusarial contamination on seed potatoes. American Journal of Potato Research 52: 211-218.

Leslie, J.F., and B.A. Summerell. 2006. The Fusarium Laboratory Manual. Blackwell Publishing Professional, First ed

Logrieco, A., S.W. Peterson, and A. Bottalico. 1995. Phylogenetic relationship within Fusarium sambucinum Fückel sensu lato, determined from ribosomal RNA sequences. Mycopathologia 129: $153-158$

Mari, M., F. Neri, and P. Bertolini. 2007. Novel approaches to prevent and control postharvest diseases of fruit. Stewart Postharvest Review 3: $1-7$.

McDonald, B.A., and C. Linde. 2002. The population genetics of plant pathogens and breeding strategies for durable resistance. Euphytica 124: 163-180.

Mishra, P.K., R.T. Fox, and A. Culham. 2003. Development of a PCRbased assay for rapid and reliable identification of pathogenic Fusaria. Microbiology Letters 218: 329-332.
Nelson, P.E., T.A. Toussoun, and W.F.O. Marasas. 1983. Fusarium Species: An Illustrated Manual for Identification. University Park: Pennsylvania State University Press.

Nicholson, P., D.R. Simpson, A.H. Wilson, E. Chandler, and M. Thomsett. 2004. Detection and differentiation of trichothecene and enniatin-producing Fusarium species on small-grain cereals. European Journal of Plant Pathology 110: 503-514.

Nirenberg, H.I. 1995. Morphological differentiation of Fusarium sambucinum Fückel sensu stricto, F. torulosum (Berk. \& Curt.) Nirenberg comb. nov., and $F$. venenatum Nirenberg sp. nov. Mycopathologia, 129, 131-141.

Nolte, P., M. Bertram, M. Bateman, and C.S. McIntosh. 2003. Comparative effects of cut and treated seed tubers vs. untreated whole seed tubers on seed decay, Rhizoctonia stem canker, growth, and yield of Russet Burbank Potatoes. American Journal of Potato Research 80: 1-8.

O'Donnell, K., and E. Cigelnik. 1997. Two divergent intragenomic rDNA ITS2 types within a monophyletic lineage of the fungus Fusarium are nonorthologous. Molecular and Phylogenetic Evolution 7: 103-116.

O’Donnell, K., E. Cigelnik, and H.I. Nirenberg. 1998. Molecular systematics and phylogeography of the Gibberella fujikuroi species complex. Mycologia 90: 465-493.

O’Donnell, K. 1992. Ribosomal DNA internal transcribed spacers are highly divergent in the phytopathogenic ascomycete Fusarium sambucinum (Gibberella pulicaris). Current Genetics 22: 213-220.

Orlikowski, L.B., and C.Z. Skrzypczak. 2003. Grapefruit extract as biocontrol agent of soil-borne and leaf pathogens. Bulletin of the Polish Academy of Sciences. Biological Sciences 2: 79-85.

Patkowska, E. 2006. Effectiveness of grapefruit extract and Pythium oligandrum in the control of bean and peas pathogens. Journal of Plant Protection Research 46: 15-28.

Peters, R.D., C. MacLeod, K.A. Seifert, R.A. Martin, L.R. Hale, C.R. Grau, et al. 2008. Pathogenicity to potato tubers of Fusarium spp. isolated from potato, cereal and forage crops. American Journal of Potato Research 85: 367-374.

Powelson, M.L., K.B. Johnson, and R.C. Rowe. 1993. Management of diseases caused by soil borne pathogens. In Potato Health Management, ed. R.C. Rowe, 149-158. St. Paul. Mennesota: The American Phytopathological Society.

Schoch, C.L., K.A. Seifert, S. Huhndorf, V. Robert, J.L. Spouge, C.A. Levesque, W. Chen, and Fungal Barcoding Consortium, 2012. Nuclear ribosomal internal transcribed spacer (ITS) region as a universal DNA barcode marker for Fungi. www.pnas.org/cgi/doi/ 10.1073/pnas.1117018109. Published 27 March 2012

Secor, G.A., and N.C. Gudmestad. 1999. Managing fungal diseases of potato. Canadian Journal of Plant Pathology 21: 213-221.

Secor, G.A., and B. Salas. 2001. Fusarium dry rot and Fusarium wilt. In Compendium of Potato Diseases, 2 nd ed., eds. W.R. Stevenson, $R$. Loria, G.D. Franc, D.P. Weingartner, 23-25. St. Paul. Mennesota: The American Phytopathological Society.

Sharma, N., and A. Tripathi. 2006. Fungitoxicity of the essential oil of Citrus sinensis on post-harvest pathogen. World Journal of Microbiology and Biotechnology 22: 587-593.

Stevenson, W.R., R. Loria, G.D. Franc, and D.P. Weingartner. 2001. Compendium of Potato Diseases. Mennesota: American Phytopathological Society.

Tan, M.-K., and L.M. Niessen. 2003. Analysis of rDNA ITS sequences to determine genetic relationships among, and provide a basis for simplified diagnosis of, Fusarium species causing crown rot and head blight of cereals. Mycological Research 107: 811-821.

Taskeen-Un, N., A.H. Wani, and R.A. Mir. 2011. Fusarium rot of potato and its management in Kashmir valley. Journal of Plant Disease Sciences 6: 107-113. 
Theron, D.J. 1991. Prediction of potato dry rot based on the presence of Fusarium in soil adhering to tubers at harvest. Plant Disease 75: $126-130$

Thrane, U., and U. Hansen. 1995. Chemical and physiological characterization of taxa in the Fusarium sambucinum complex. Mycopathologia 129: 183-190.

Ueno, Y. 1983. General toxicology. In. Developments in food science. IV. Trichothecenes. Chemical, biological and toxicological aspects, ed. Y. Ueno, 135-146. Amsterdam: Elsevier.

Valluru, R., B.J. Christ, K.G. Haynes, and B.T. Vinyard. 2006. Inheritance and stability of resistance to Fusarium tuber rot in tetraploid potatoes. American Journal of Potato Research 83: 335-341.

Waalwijk, C., J.R.A. de Koning, R.P. Baayen, and W. Gams. 1996. Discordant groupings of Fusarium spp. from sections Elegans, Liseola and Diaminia based on ribosomal ITS1 and ITS2 sequences. Mycologia 88: 361-368.

Wagacha, J.M., and J.W. Muthomi. 2007. Fusarium culmorum: Infection process, mechanisms of mycotoxin production and their role in pathogenesis in wheat. Crop Protection 26: 877885.
Wharton, P.S., P. Tumbalam, and W.W. Kirk. 2006. First report of potato tuber sprout rot caused by Fusarium sambucinum in Michigan. Plant Disease 90: 1460.

White, T.J., T. Bruns, S. Lee, and J. Taylor. 1990. PCR Protocols: A guide to Methods and Applications. In Amplification and direct sequencing of fungal ribosomal RNA genes for phylogenetics, ed. M.A. Innis, D.H. Gelfand, J.J. Sninsky, and T.J. White, 315-322. San Diego: Academic.

Wilson, A., D. Simpson, E. Chandler, P. Jennings, and P. Nicholson. 2004. Development of PCR assays for the detection and differentiation of Fusarium sporotrichioides and Fusarium langsethiae. FEMS Microbiology Letters 233: 69-76.

Wisniewski, M.E., and C.L. Wilson. 1992. Biological control of postharvest diseases of fruits and vegetables. Recent Advances. HortScience 27: 94-98.

Wollenweber, H.W., and O.A. Reinking. 1935. Die Fusarien, ihre Beschreibung, Schadwirkung und Bekampfung. Verlag Paul Parey, Berlin, Germany

Yoder, W.T., and L.M. Christianson. 1998. Species-specific primers resolve members of Fusarium section Fusarium. Taxonomic status of the edible "Quorn" fungus reevaluated. Fungal Genetics and Biology 23: 68-80. 